\title{
Mawar Iteng: Program in Efforts to Improve Human Development Index (HDI) in the Health Sector
}

\author{
Luluk Fauziah $^{1}$, Johan Bhimo Sukoco ${ }^{2}$, Suwandi $^{3}$ \\ \{lulukfauziah@lecturer.undip.ac.id¹ ${ }^{1}$,johanbhimo@lecturer.undip.ac.id ${ }^{2}$, suwandi@lecturer.undip.ac.id ${ }^{3}$ \} \\ Universitas Diponegoro, Indonesia ${ }^{1,2,3}$
}

\begin{abstract}
The Human Development Index (HDI) is a way to measure the success of a country in maintaining the physical and non-physical quality of the population. The indicators include health, education level, and the economy. The purpose of this study was to describe the application of the Mawar Iteng program, including the causes of the high number of maternal mortality rate (MMR) and the efforts of health care providers to assist mothers in childbirth in Pemalang District, Central Java. Whilst the data analysis technique used an interactive analysis model with regard to 3 (three) main components: data reduction, data presentation, and drawing conclusions as well as verification. The results showed that maternal mortality during childbirth was a very complex case. Noticing from the age group, the highest percentage of maternal death cases occurred at the age of 25-40 years. Seeing this condition there needs to be interference from the family, community and government including efforts to increase family planning acceptors, improvement in the quality of services in the identification of complications, prevention of complications, first aid and stabilization of patients before making a referral and timely referral. One of the efforts to reduce maternal mortality is by examining antenatal care (ANC) and implementing the Mawar Iteng program embodying Mak'e waras bayine kentheng which means the mother is healthy at the time of delivery and the baby is safe.
\end{abstract}

Keywords: Mawar Iteng, Human Development Index, Health.

\section{Introduction}

The Human Development Index (HDI) is formed by composite indicators namely Education, Health, and Purchasing Power Parity. With the three indicators used as a parameter, it is hoped that they can be used as an instrument of how development policy in Pemalang Regency is able to guarantee at least three of the most basic choices of its population, namely the choice to live long, to possess the knowledge, and to live properly. Until 2016, the HDI in Pemalang District showed a significant increase in realization. Between 2011 and 2016, there was an increase of 4.51 points resulted in an HDI of 64.17 in 2016 as in the following table 1.

Table 1. Improvement of the Human Development Index

\begin{tabular}{|l|c|c|c|c|c|c|}
\hline \multicolumn{1}{|c|}{ Indicator } & 2011 & 2012 & 2013 & 2014 & 2015 & 2016 \\
\hline Life Expectancy (Year) & 72.37 & 72.48 & 72.59 & 72.64 & 72.77 & 72.87 \\
\hline $\begin{array}{l}\text { School Life } \\
\text { Expectancy (Year) }\end{array}$ & 10.45 & 10.64 & 11.05 & 11.26 & 11.86 & 11.87 \\
\hline
\end{tabular}




\begin{tabular}{|l|c|c|c|c|c|c|}
\hline $\begin{array}{l}\text { Average Length of } \\
\text { School Year (Year) }\end{array}$ & 5.19 & 5.51 & 5.72 & 5.87 & 6.04 & 6.05 \\
\hline $\begin{array}{l}\text { Adjusted Per Capita } \\
\text { Expenditure (Rp.000) }\end{array}$ & 6.488 & 6.725 & 6.863 & 6.911 & 7.177 & 7.447 \\
\hline HDI & 59.66 & 60.78 & 61.81 & 62.35 & 63.70 & 64.17 \\
\hline
\end{tabular}

Source: Statistics Indonesia (BPS) of Pemalang Regency, 2017 [1].

Along with economic growth, improvement of the physical and mental quality of the population is carried out through development in the field of education and health. Its development program is designed to expand the reach of basic education and health services. In the economic sector, the principle of equality that is implemented is estimated to have a major influence on employment. Employment and health opportunities are pursued at a macroeconomic level through high and sustainable economic growth pathways. This is because the growth of employment and business will enable a significant increase in population income. In the end, it will reduce the number of people living below the poverty line.

Living a longer life is everyone's dream, therefore, good health is the key. Human development broadens human choices by requiring long life. Prolonged and healthy life proxies used in human development are indicators of life expectancy at birth (e0). This indicator is an indicator of public health. Education gives someone a greater opportunity. In simple terms, development can be interpreted as an effort or process to make changes for the better. The development process occurs in all aspects of community life, such as economic, political, social, and cultural aspects [2].

As one aspect to improve the welfare of the population, physical quality improvement of the population can be seen from the overall health status of the population. One of the main indicators used to assess the health status of the population is the morbidity rate. The development program in the health sector aims to improve the health rate and status of the population which is expected to increase the population productivity to achieve prosperity. Therefore, to measure health status, morbidity is used. The morbidity rate is defined as the percentage of the population experiencing health problems and disturbed their daily activities. The table below explains that the morbidity rate in Pemalang District, both male and female residents are relatively the same. As in the table 2 .

Table 2. Population Health Rate

\begin{tabular}{|c|c|c|c|c|}
\hline No & Detail & 2013 & 2014 & 2015 \\
\hline \multicolumn{5}{|c|}{ Morbidity Rate } \\
\hline 1 & Male & 7,03 & 8,33 & 18,53 \\
\hline 2 & Female & 10,32 & 10,84 & 17,74 \\
\hline \multicolumn{2}{|r|}{ Total } & 8,70 & 9,60 & 18,13 \\
\hline \multicolumn{5}{|c|}{ The average duration of being ill } \\
\hline 1 & $<4$ & 96,20 & 96,01 & 43,01 \\
\hline 2 & $4-7$ & 2,64 & 3,00 & 42,65 \\
\hline 3 & $8-30$ & 1,16 & 0,99 & 14,35 \\
\hline
\end{tabular}

Source: Department of Health, 2015 [3].

The target of the Regency government in implementing SDGs (2016-2030) Social Pillars, among others, by 1 ) reducing the poverty rate by $7 \%$ to $8 \%$. 2) Increasing access to water and 
sanitation $100 \%$. 3) Reducing infant mortality rate per 1000 births and 102 maternal mortality rates per 100,000 births. 4) Increasing health facilities by $85 \%$ and health insurance coverage by $100 \%$. 5) Increasing gross participation by $114.09 \%$ for elementary schools, $106.94 \%$ for junior high schools, and $91.63 \%$ for high schools.

Maternal mortality is the death of a woman during pregnancy, childbirth, or in the 42 days after the pregnancy due to all causes related to or exacerbated by pregnancy or treatment, but not caused by accident or injury. While the Maternal Mortality Rate is the number of maternal deaths due to the process of pregnancy, childbirth, and post-natal condition per 100,000 live births at a certain time.

Graph 1. Number of Maternal Mortality In 2018

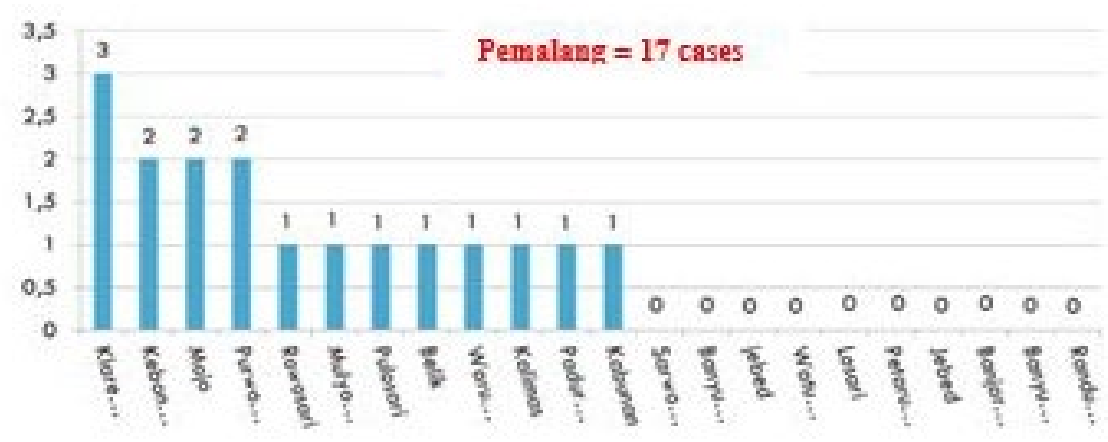

Source: Pemalang Regency, 2018 [4].

Based on the data description above, the problem in this study is how the application of the "Mawar Iteng" program in Pemalang Regency and what is the cause of high Maternal Mortality Rate (MMR) and how the efforts of health service providers to assist mothers in childbirth in Pemalang district.

\section{Research Method}

This research employed a descriptive qualitative method by describing the application of the "Mawar Iteng" program. Data collection techniques include an unstructured interview, participant observation, and document analysis (reviewing documents and giving implied meaning) as well as Focus Group Discussion (FGD). The data obtained were analyzed using interactive analysis model concerning 3 (three) main components, including data reduction, data presentation, and conclusion drawing along with its verification.

\section{Result and Discussion}

\subsection{Definition of the Human Development Index}


UNDP provides the understanding that human development is a process to provide more diverse choices for humans. The concept or definition of human development covers a very broad dimension of development. In the concept of human development, development should be analyzed and can be understood from the point of human beings, not just from economic growth. As quoted from UNDP [5], a number of important premises in human development are:

a) Development must prioritize the population as the center of attention.

b) The development is to provide more choices for the population, not only to increase their income. Therefore, the human development concept must be centered on the population as a whole, and not just on the economic aspects.

c) Human development focuses its attention not only on efforts to improve human capabilities, but also to optimally utilize these capabilities.

d) Human development is supported by four main pillars, namely productivity, equity, sustainability, and empowerment.

e) Human development is the basis for determining development goals and in analyzing options for achieving them.

HDI is an index that measures the achievement of socio-economic development of a region or country which combines achievement in the fields of education, health, and adjusted real income per capita. According to UNDP [5], in the Human Development Index (HDI), there are three composite indicators used to measure the average achievement of a country in human development, namely length of life, measured by life expectancy at birth; education, measured based on average length of school year and literacy rates of people aged 15 years and above; standard of living, measured by adjusted per capita expenditure that becomes a priority of purchasing power. The index value ranges from 0-100.

\subsection{Human Development Policy in Pemalang Regency}

Pemalang Regency Development as stipulated in PERDA (Local Regulation) Number 12 of 2016 concerning RPJMD is the development that adheres to the concept of improving the population quality of life physically, mentally, and spiritually [6]. It was stated that the development carried out focused on the physical and mental development of human resources which implies an increase in the population basic capacity which would then broaden the opportunity to be able to participate in a sustainable development process.

Along with economic growth, physical and mental development of population is carried out through the development in the fields of education and health of which the development program is designed to expand the reach of basic education and health services. In the economic sector, the principle of equality that is implemented is estimated to have a major influence on employment. Employment and health opportunities are carried out in a microeconomic manner through high and sustainable economic growth pathways. This is because the growth of employment and business opportunities will enable a significant increase in income of the population which will reduce the number of people living below the poverty line. This is the main bridge in improving the principle of empowerment.

A very impressive social development is the effort to control the population through the family planning program. This effort has significantly reduced the birth rate by half which then able to reduce the rate of population growth. From a development perspective, the success of reducing the rate of population growth is an effort that will accelerate the improvement in life quality [7]. 


\subsection{Maternal Mortality Rate}

The World Health Organization [8] states that the Maternal Mortality Rate (MMR) is an indicator used to determine the number of maternal health problems. MMR is the number of female deaths during pregnancy or during 42 days from termination of pregnancy regardless the length and place of delivery, which is not due to other reasons but pregnancy and treatment, per 100,000 live births.

Maternal Mortality Rate (MMR) is an indicator to see the degree of women's health. The Maternal Mortality Rate is also one of the targets that have been determined in the Millennium Development Goals, namely the fifth goal, which is to improve maternal health. The target is to reduce the risk of the number of maternal mortalities by $3 / 4$. The fifth Millennium Development Goals (MDGs) are to reduce MMR to 102 per 100,000 live births by 2015 . However, in reality, the target has not been successful and it requires hard work from various parties to do so [3].

\subsection{Discussion}

\subsubsection{HDI Improvement Strategies in the Health Sector}

The Human Development Index (HDI) is an important indicator to measure success in efforts to build life quality of human beings/population. HDI can also be used to determine the development ranking or level of an area. HDI in Indonesia is a strategic data because aside from being a measure of Government performance, HDI is also used as one of the allocators for determining the General Allocation Fund. The low HDI in Pemalang Regency is inseparable from various problems that are interrelated with one another.

Environmental problems are still a major problem in the health sector. This can be seen from many health facilities in the household which are still categorized as inadequate. The poverty factor is a major problem for households in providing adequate household health facilities. Health infrastructure is also still considered to be very lacking especially hospitals in the Southern and Eastern Pemalang. Not to mention the lack of implementation of health supervision for pregnant women and malnutrition. Although relatively small, but hereditary factors cannot be ignored in improving the degree of public health, as well as public awareness of healthy living behavior. In connection with these problems the Pemalang Regency makes strategies and programs to improve HDI, especially the health sector as in the following table:

Table 3. Matrix of Strategy and HDI Improvement Program in the Health Sector

\begin{tabular}{|c|c|c|c|}
\hline No & Problems & Program & Stakeholder \\
\hline 1 & $\begin{array}{l}\text { Environment: } \\
\text { - There are still households } \\
\text { in Pemalang that do not } \\
\text { have a toilet. } \\
\text { - There are still households } \\
\text { with access to proper } \\
\text { sanitation and clean water } \\
\text { The poverty factor which } \\
\text { resulted in malnutrition } \\
\text { causing the condition of } \\
\text { pregnant women to suffer }\end{array}$ & $\begin{array}{l}\text { Building healthy toilets } \\
\text { for families who do not } \\
\text { yet have healthy toilets } \\
\text { Improving the coverage } \\
\text { of drinking water and } \\
\text { sanitation (clean water } \\
\text { pipeline) } \\
\text { - Restoration of unliveable } \\
\text { houses } \\
\text { - Improvement of poverty }\end{array}$ & 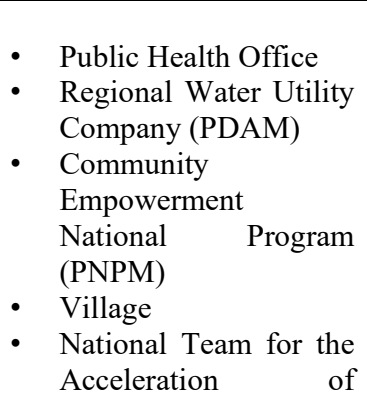 \\
\hline
\end{tabular}




\begin{tabular}{|c|c|c|c|}
\hline & $\begin{array}{l}\text { from chronic energy } \\
\text { deficiency and } \\
\text { malnutrition toddlers }\end{array}$ & programs & $\begin{array}{ll}\text { Poverty } & \text { Reduction } \\
\text { (TNP2K) } & \end{array}$ \\
\hline 2 & $\begin{array}{l}\text { Health Services: } \\
\text { - Availability and } \\
\text { affordability of health } \\
\text { facilities } \\
\text { Unequal supervision of } \\
\text { health implementation for } \\
\text { mothers and babies } \\
\text { The implementation of } \\
\text { family planning programs } \\
\text { that is not yet optimal }\end{array}$ & 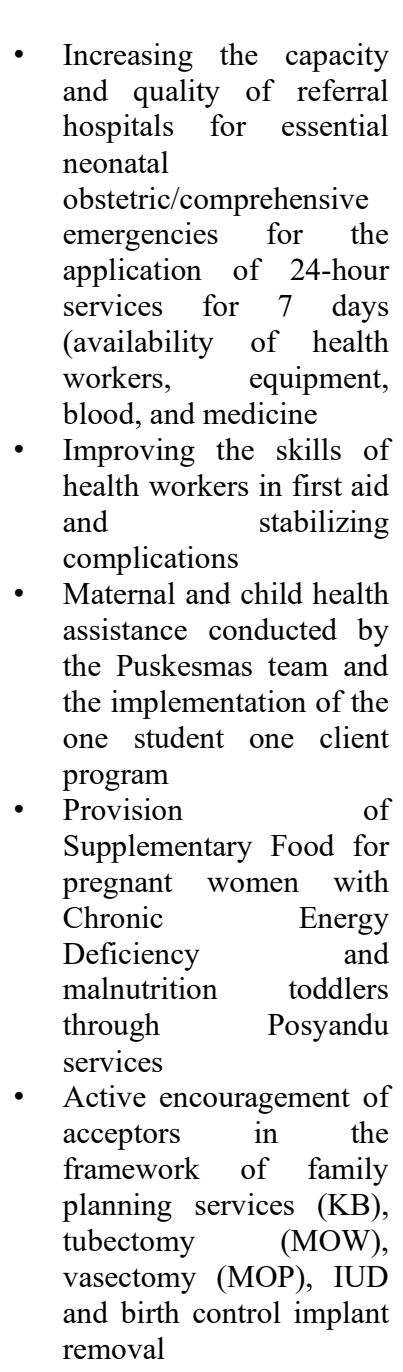 & $\begin{array}{ll}\text { - } & \text { Public Health Office } \\
\text { - } & \text { Indonesian Doctors } \\
\text { - Association (IDI) } \\
\text { Indonesian Midwives } \\
\text { - } \\
\text { Association (IBI) } \\
\text { Posyandu }\end{array}$ \\
\hline 3 & $\begin{array}{l}\text { Health Behavior: } \\
\text { - Still oriented toward } \\
\text { traditional medicine due } \\
\text { to lack of education }\end{array}$ & $\begin{array}{l}\text { - Socialization of health } \\
\text { behavior from the family } \\
\text { level to the wider } \\
\text { community }\end{array}$ & $\begin{array}{l}\text { - Village } \\
\text { - Family Welfare } \\
\text { Empowerment (PKK) }\end{array}$ \\
\hline 4 & $\begin{array}{l}\text { Heredity: } \\
\text { - There are still many } \\
\text { diseases caused by } \\
\text { hereditary factors }\end{array}$ & $\begin{array}{l}\text { Improving healthy living } \\
\text { behaviour }\end{array}$ & $\begin{array}{ll}\text { - } & \text { Government } \\
\text { - } & \text { Society }\end{array}$ \\
\hline
\end{tabular}

Source: Research Results (processed), 2019. 


\subsubsection{Mawar Iteng Program (Ma'e Waras Bayine Kentheng)}

Activities undertaken by the society in Pemalang Regency in reducing maternal mortality include: 1) record and meet pregnant women or called Tilik Ma'e (find pregnant women); 2) Engaging society/family; 3) Conduct regular checks; 4) Remind integrated antenatal care; 5) Consult a doctor; 6) Take advantage of National Health Insurance; 7) Exclusive breastfeeding; 7) educate pregnant women. More details are presented in the following table:

Table 4. Mawar Iteng Program in Pemalang District

\begin{tabular}{|c|c|}
\hline Program & Cross-cutting role \\
\hline 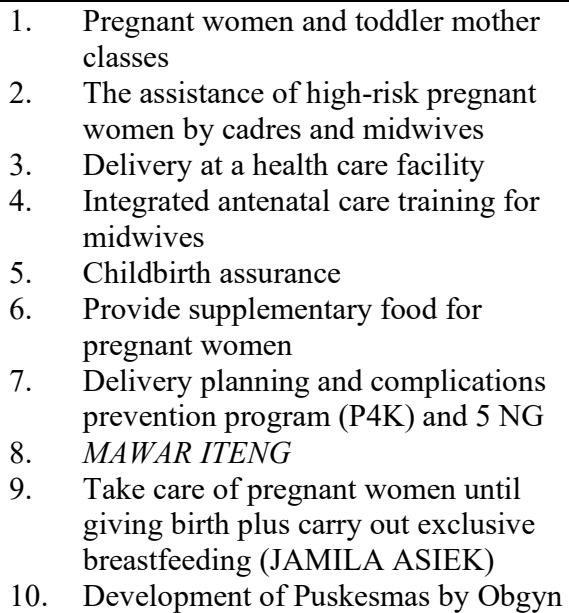 & $\begin{array}{ll}\text { 1. } & \text { Reproductive Health Education in Schools } \\
\text { 2. } & \text { Female workers (nutritional counseling and } \\
\text { supplementation with blood tablets) } \\
\text { 3. Premarital family planning counseling } \\
\text { 4. Institutional strengthening of the } \\
\text { operational working group (POKJANAL) } \\
\text { 5. Strengthening Posyandu cadres } \\
\text { 6. Health Services in Early Childhood } \\
\text { 7. Education } \\
\text { Institutional strengthening of the School } \\
\text { 8. } \quad \begin{array}{l}\text { Health Development Team } \\
\text { check-ups }\end{array} \\
\text { 9. Use of health report cards } \\
\text { 10. Strengthening Puskesmas human resources }\end{array}$ \\
\hline
\end{tabular}

\subsubsection{Jamila (Take care of pregnant women until giving birth plus carry out exclusive breastfeeding)}

Is an integrated empowerment effort for pregnant women and their companions (husband or family members) to foster the support and active participation of a companion to empower themselves more in sharing responsibilities with his wife. The targets of this program are husbands or family members and pregnant women with high risk.

\subsubsection{Causes of Mothers' Death}

Low public awareness that the health of pregnant women is a determinant of mortality, although there are still many factors that must be considered to deal with this problem. Mortality problems occurring are caused by indicators that commonly arise, namely hemorrhage (bleeding), pregnancy poisoning accompanied by seizures (preeclampsia/eclampsia), abortion, and infection. Hemorrhage is a major cause of maternal mortality from year to year. Hemorrhage is caused by mothers who give birth at too young ages, those who are too old, too often or too close between one and another birth. Other contributing causes are degenerative diseases suffered by mothers such as cancer, heart, kidney, and tuberculosis. Therefore, labor by health workers in health facilities is considered very important. However, it turns out that the maternal mortality factors mentioned above are not the only cause of the high MMR in Pemalang Regency. In addition to medical problems, 
high maternal mortality is also due to the issue of gender inequality, cultural values, economy, and low attention of men toward pregnant and childbirth women. Therefore, the view that considers pregnancy as a natural phenomenon needs to be changed socio culturally so that women can get attention from society. Efforts are needed to improve maternal care services by the government, private sector, and the society, especially the husband.

Three main factors causing maternal mortality, namely hemorrhage hypertension during pregnancy or preeclampsia and infection. Hemorrhage occupies the highest percentage of maternal mortality causes. Hemorrhage and infection are mainly caused by anemia and chronic energy deficiency in pregnant women. Eclampsia is the second main cause of maternal mortality in which seizures can occur in patients with uncontrolled hypertension during labor. Hypertension can occur due to pregnancy and will return to normal when the pregnancy is over. However, some still experience hypertension even though the baby has been born. This condition will become more severe if the mother has already had hypertension before pregnancy. The third cause of maternal mortality is an infection (11\%). As presented in the graph below.

Graph 2. Causes of Maternal Mortality

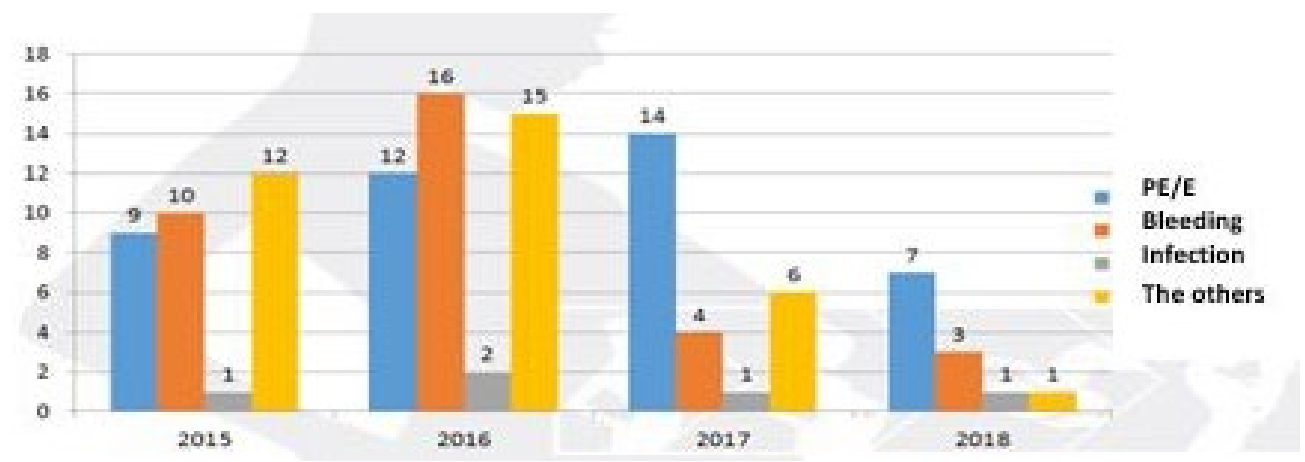

Source: Statistics of Pemalang regency, 2018 [4].

\subsubsection{Efforts of Health Service Providers}

Efforts to accelerate the MMR reduction to achieve the 2015 MDGs target which was continued in the SGDs program (2015-2030). The Directorate of Maternal Health Development has formulated the following scenarios for the MMR reduction as follows:

a) Millennium Development Goals (MDGs) 5 will be achieved if $50 \%$ of maternal mortality per province can be prevented/reduced.

b) The first antenatal visit (K1) should be done at least in the first trimester to encourage an increase in the coverage of four-time antenatal visits (K4).

c) Midwives in the village should stay to make a positive contribution to laboring assistance and maternal complication prevention and management.

d) Laboring must be assisted by health workers and wherever possible in a health facility.

e) Family planning services must be improved to reduce risk factors 4 .

f) Family and society empowerment in gender-responsive reproductive health must be increased to improve healthcare-seeking behavior. 
To overcome this, the National Population and Family Planning Agency (BKKBN) conducted a marriage age maturity program at various information centers, both at schools, universities, and others. Besides, by collaborating, up to now, there are 49 working partners and stakeholders including government and private, foundations, and organizations to help reduce the number of deaths.

\section{Conclusion}

The Human Development Index (HDI) is an important indicator to measure success in efforts to build human beings' quality of life. HDI can also be used to determine the rank or level of area development. Low public awareness about the health of pregnant women is a determinant of mortality, although there are still many factors that must be considered to deal with this problem. Furthermore, the efforts of health service providers are further enhanced, especially in providing referral letters needed by patients, especially pregnant women. In addition, infrastructure needs to be improved, especially that is related to several things that support, including the hospitals and clinics needed for pregnant women and equipped with adequate medical personnel. After implementation of Mawar Iteng program, there is no HDI improvement, especially in health sector.

\section{References}

[1] Badan Pusat Statistik, Indeks Pembangunan Manusia Tahun 2017: Metode Baru. 2017.

[2] M. P. Todaro and S. C. Smith, "Pembangunan Ekonomi Jilid 1," Jakarta: Erlangga, 2006.

[3] Departemen Kesehatan RI, Profil Kesehatan Indonesia. Jakarta: Departemen Kesehatan RI, 2015.

[4] Badan Pusat Statistik Kabupaten Pemalang, Pemalang dalam Angka. Pemalang, 2018.

[5] UNDP, Humant Development Report. New York: Oxford University Press, 2000.

[6] Peraturan Daerah Kabupaten Pemalang, Peraturan Daerah Kabupaten Pemalang Nomor 12 Tahun 2016 Tentang Rencana Pembangunan Jangka Menengah Daerah (RPJMD). 2016.

[7] W. D. Artaningtyas, A. Syari'udin, and T. Maryani, "Analisis Indeks Pembangunan Manusia di Provinsi Jawa Tengah,” Bul. Ekon., vol. 9, no. 1, pp. 51-58, 2011.

[8] World Health Organization, Maternal Mortality in 2000. Departemen of Reproductive Health and Research Genewa-WHO, 2004. 